\title{
PENERAPAN MODEL PEMBELAJARAN TREFFINGER BERBANTUKAN SOFTWARE SPARKOL VIDEOSCRIBE UNTUK MENINGKATKAN PEMAHAMAN MATEMATIS SISWA
}

\author{
Siti Aisyah ${ }^{1}$, Evi Widayanti ${ }^{2}$ \\ ${ }^{1}$ STKIP Bina Insan Mandiri \\ aisyahcity15@gmail.com \\ ${ }^{2}$ STKIP Bina Insan Mandiri \\ eviwidayanti@stkipbim.ac.id
}

\begin{abstract}
ABSTRAK
Penelitian ini bertujuan untuk mengetahui pemahaman matematis siswa kelas $\mathrm{X}$ SMA Muhammadiyah 4 Surabaya. Dari hasil tes, diketahui pemahaman matematis siswa kelas X IPA SMA Muhammadiyah 4 Surabaya adalah rendah. Untuk mengatasinya, diterapkan model pembelajaran treffinger berbantukan software sparkol videoscribe. Metode penelitian ini adalah PTK dengan pola kolaboratif. Dari penelitian ini dapat diketahui bahwa terdapat peningkatan rata- rata dari 48,62 (rendah) menjadi 80,34 (baik). Selain itu, dapat diketahui bahwa Kemampuan menyatakan ulang konsep yang telah dipelajari meningkat dari 58,62\% menjadi $72,41 \%$; Kemampuan menerapkan konsep secara algoritma meningkat dari 41,38\% menjadi 86,21\%; Kemampuan memberikan contoh dan counter example dari konsep yang telah dipelajari meningkat dari 20,69 \% menjadi 58,62\%; Kemampuan menyajikan konsep dalam berbagai macam bentuk representasi matematika meningkat dari 10,34\% menjadi 79,31\%; serta Kemampuan mengaitkan berbagai konsep (internal dan eksternal matematika) meningkat dari $0 \%$ menjadi $24,14 \%$. Berdasarkan temuan penelitian ini, maka model pembelajaran treffinger berbantukan software sparkol videoscribe dapat digunakan sebagai alternatif untuk meningkatkan pemahaman matematis siswa.
\end{abstract}

Kata Kunci: pembelajaran treffinger, pemahaman matematis, media pembelajaran, sparkol videoscribe.

\begin{abstract}
This study aims to determine the mathematical understanding of students of class X of SMA Muhammadiyah 4 Surabaya. From the result of the test, it is known that the mathematical understanding of class X IPA of SMA Muhammadiyah 4 Surabaya is low. To overcome this, applied treffinger learning model with software sparkol videoscribe. The research method used is a Class Action Research (PTK) with a collaborative pattern. From this study, it can be seen that there is an average increase from 48,62 (low) to 80,34 (good). In addition, it can be known that the ability to reiterate the concept learned has increased from $58.62 \%$ to $72.41 \%$; Ability to apply the concept algorithmically increased from $41.38 \%$ to $86.21 \%$; Ability to give examples and counter-example of the concepts studied increased from $20.69 \%$ to $58.62 \%$; Ability to present concepts in various forms mathematical representation increased from $10.34 \%$ to $79.31 \%$; and Ability to link various concepts (internal and external mathematics) increased from $0 \%$ to $24.14 \%$. Based on the findings in this study,
\end{abstract}


the treffinger learning model using the software sparkol videoscribe can be used as an alternative to improve students' mathematical understanding.

Keywords: treffinger learning, mathematical understanding, learning media, sparkol videoscribe.

Format Sitasi: Aisyah, S., \& Widayanti, E. (2019). Penerapan Model Pembelajaran Treffinger Berbantukan Software Sparkol Videoscribe untuk Meningkatkan Pemahaman Matematis Siswa Kelas X. Kalamatika: Jurnal Pendidikan Matematika, 4(2), 117-128.

Penyerahan Naskah: 21 Januari 2019 || Revisi: 24 Oktober 2019 || Diterima: 28 November 2019

\section{PENDAHULUAN}

Program for International Student Assessment (PISA) adalah suatu program untuk menilai kemampuan siswa dalam lingkup Internasional. PISA dikelola oleh Organisation for Economic Cooperation and Development (OECD). Di Indonesia, hasil tes dan evaluasi pada tahun 2015 yang dilakukan oleh Programme for International Students Assessment (PISA) melaporkan bahwa dari jumlah 540.000 siswa, Indonesia menduduki peringkat 63 dari 70 negara untuk matematika dengan skor 386. Hal ini memperlihatkan bahwa Indonesia masih tergolong rendah dalam penguasaan materi.

Menurut OECD (Susanti \& Syam, 2017) kemampuan literasi matematika siswa Indonesia masih tergolong rendah. Hal tersebut bertolak belakang dengan salah satu amanat Menteri Pendidikan dan Kebudayaan. Berdasarkan Peraturan Menteri Pendidikan dan Kebudayaan Nomor 20 Tahun 2016 tentang Standar Kompetensi Lulusan Pendidikan Dasar dan Menengah telah diamanatkan kepada siswa Indonesia agar dapat memiliki keterampilan berpikir dan bertindak kreatif, produktif, kritis, mandiri, kolaboratif, dan komunikatif. Namun, ada hal penting yang harus dilewati sebelum membuat siswa memiliki keterampilan berpikir kreatif yang tinggi yaitu siswa harus memiliki pemahaman matematis yang tinggi terlebih dahulu.

Peneliti telah melakukan tes pemahaman matematis siswa kelas X IPA 1 SMA Muhammadiyah 4 Surabaya. Dari tes tersebut, dapat diketahui bahwa pemahaman matematis mereka termasuk dalam kriteria kurang dengan rata- rata 48,62. Dikatakan masuk dalam kategori kurang sesuai dengan kriteria pemahaman matematis yang terdapat pada tabel 1. Oleh karena itu, peneliti tertarik untuk mencari solusi agar pemahaman matematis mereka dapat meningkat. 
Hasil penelitian yang dilakukan oleh Retnowati (2013) menunjukkan bahwa model pembelajaran treffinger dapat meningkatkan pemahaman matematis siswa. Sedangkan hasil penelitian yang dilakukan oleh Oktavia (2017) menunjukkan bahwa model pembelajaran treffinger dapat mendorong siswa untuk belajar secara kreatif.

Menurut Safar (2016) sparkol videoscribe merupakan salah satu alat bantu visual yang dapat membantu akademisi, pendidik, teknologi instruksional, praktisi, administrator serta pembuat kebijakan dan keputusan dalam memastikan dan menentukan solusi yang tepat untuk mengatasi tantangan pendidikan. Sparkol videoscribe juga dianggap relevan dan dapat diandalkan dalam meningkatkan proses pendidikan berpikir, mengajar, belajar dan memimpin di era pengetahuan digital. Sehingga, software ini cocok digunakan untuk meningkatkan pemahaman matematis siswa.

Nurkaeti (2017) mengatakan kemampuan pemahaman matematis adalah kemampuan seseorang dalam menginterpretasi konsep, aturan, dan hubungan antar konsep matematis, sehingga siswa dapat memecahkan masalah bukan sekedar hapalan saja. Sedangkan pemahaman matematis dalam penelitian ini adalah kemampuan siswa dalam menyatakan ulang konsep yang telah dipelajari, menerapkan konsep secara algoritma, memberikan contoh dan counter example dari konsep yang telah dipelajari, menyajikan konsep dalam berbagai macam bentuk representasi matematika, serta mengaitkan berbagai konsep (internal dan eksternal matematika).

Indikator pemahaman matematis yang biasanya dipakai para ahli menurut Dahlan (2011) adalah sebagai berikut:

1. Kemampuan menyatakan ulang konsep yang telah dipelajari, yakni kemampuan siswa untuk mengungkapkan kembali apa yang telah dikomunikasikan kepadanya

2. Kemampuan mengklasifikasi objek-objek berdasarkan dipenuhi atau tidaknya persyaratan yang membentuk konsep tersebut, yakni kemampuan siswa mengelompokkan suatu objek menurut jenisnya berdasarkan dipenuhi atau tidaknya persyaratan yang membentuk konsep

3. Kemampuan menerapkan konsep secara algoritma, yakni kemampuan siswa menggunakan konsep serta prosedur dalam menyelesaikan soal yang berkaitan dengan kehidupan sehari-hari 
4. Kemampuan memberikan contoh dan counter example dari konsep yang telah dipelajari, yakni kemampuan siswa untuk dapat membedakan contoh dan bukan contoh dari suatu materi

5. Kemampuan menyajikan konsep dalam berbagai macam bentuk representasi matematika, yakni kemampuan siswa memaparkan konsep secara berurutan yang bersifat matematis

6. Kemampuan mengaitkan berbagai konsep (internal dan eksternal matematika), yakni kemampuan siswa menghubungkan berbagai konsep matematika dan ilmu lain

7. Kemampuan mengembangkan syarat perlu dan atau syarat cukup suatu konsep, yakni kemampuan siswa mengkaji mana syarat perlu dan mana syarat cukup yang terkait dalam suatu konsep materi.

Namun dari tujuh indikator tersebut tidak dipenuhi semuanya, karena indikator kemampuan mengklasifikasikan objek- objek berdasarkan dipenuhi tidaknya persyaratan yang membentuk konsep tersebut dan indikator kemampuan mengembangkan syarat perlu dan syarat cukup suatu konsep diabaikan.

Model pembelajaran treffinger dalam penelitian ini adalah model pembelajaran yang menggunakan proses berfikir divergen disertai dengan kemampuan menerapkan konsep secara algoritma dan memberikan contoh dan counter example dari konsep yang telah dipelajari. Ada 2 macam tahapan model pembelajaran Treffinger yaitu menurut Treffinger dan Munandar. Treffinger (Huda, 2013) menyebutkan bahwa model pembelajaran ini terdiri atas 3 komponen penting yaitu Understanding Challenge, Generating Ideas, dan Preparating for Action. Sedangkan menurut Munandar (Shoimin, 2014) terdiri dari langkah- langkah berikut: basic tools, practice with process, dan working with real problem. Penelitian ini menggunakan tahap yang dikemukakan oleh Munandar.

Berdasarkan permasalahan yang telah dipaparkan, maka rumusan masalah dalam penelitian ini adalah "Bagaimana pemahaman matematis siswa melalui penerapan model pembelajaran treffinger berbantukan software sparkol videoscribe pada siswa kelas X IPA 1 SMA Muhammadiyah 4 Surabaya?"

\section{METODE PENELITIAN}

Metode penelitian yang digunakan adalah PTK dengan pola kolaboratif. Rancangan penelitian ini menggunakan adaptasi model Hopkins (Sanjaya, 2011). Dimana pada tahap 
identifikasi masalah merupakan tahap pra siklus, sedangkan tahap siklus 1 meliputi perencanaan; aksi; observasi; dan refleksi. Adapun skema model tersebut adalah sebagai berikut (Sanjaya, 2011).

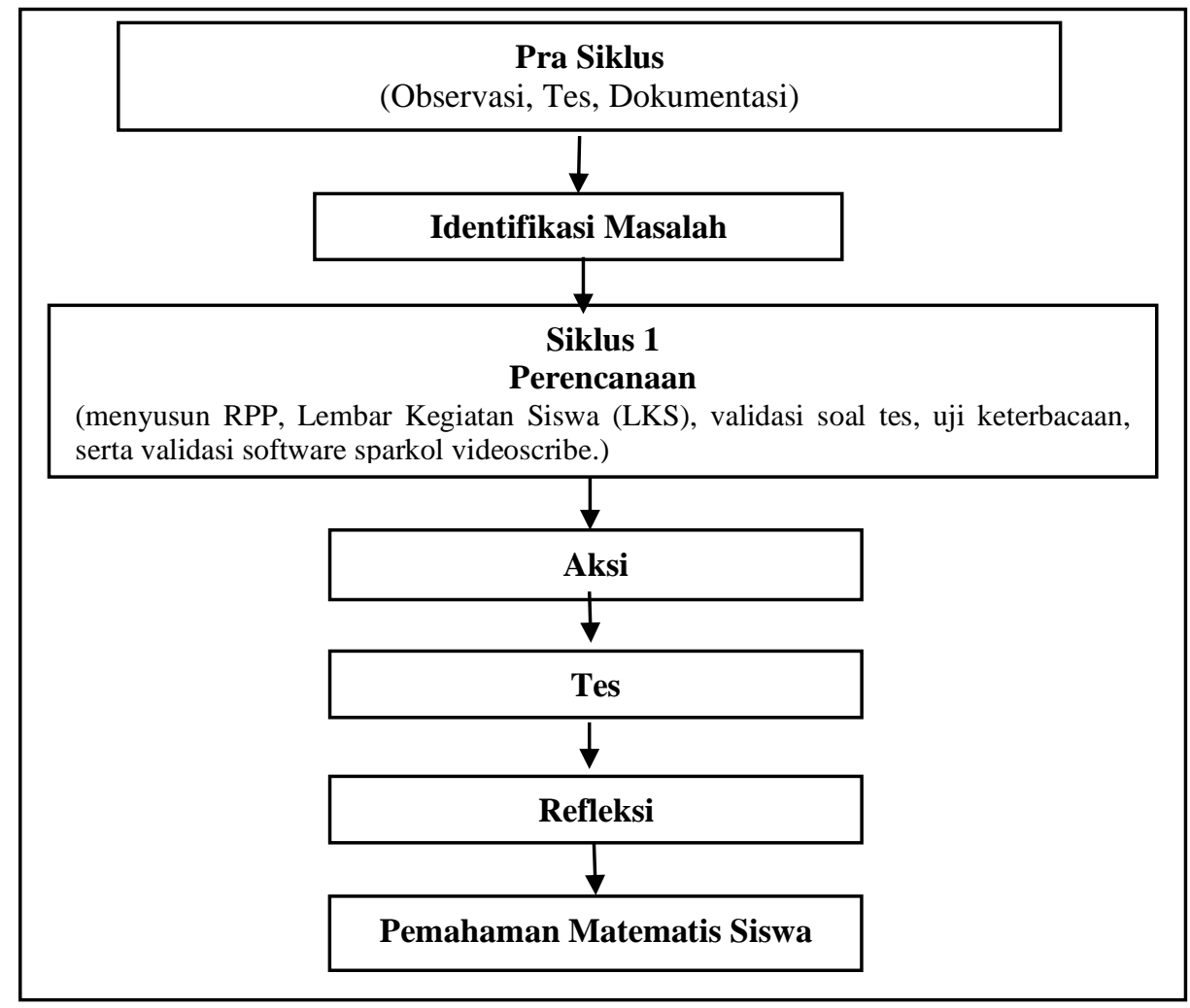

Gambar 1. Adaptasi Rancangan Penelitian Model Hopkins

Teknik pengumpulan data penelitian ini adalah tes, observasi, serta dokumentasi. Teknik analisis data yang digunakan adalah deskriptif kuantitatif dan statistik deskriptif. Deskriptif kuantitatif digunakan untuk penilaian hasil tes individu. Rumusnya mengacu pada Sudijono (2010).

$$
\text { Nilai }=\frac{\text { Skor Mentah }}{\text { SkorMaksimum Ideal }} \times 100
$$

Kemudian nilai pemahaman matematis tersebut dapat diinterpretasikan mengacu kepada tabel 1 adaptasi dari Dinas Pendidikan (Zulkarnain \& Djamilah, 2015).

Tabel 1. Interpretasi Pemahaman Matematis Individu

\begin{tabular}{lc}
\hline \multicolumn{1}{c}{ Nilai } & Kriteria \\
\hline$\geq 95,00$ & Istimewa \\
$80,00-94,99$ & Amat Baik \\
$65,00-79,99$ & Baik \\
$55,00-64,99$ & Cukup \\
$40,00-54,99$ & Kurang \\
$<40,00$ & Amat Kurang \\
\hline
\end{tabular}


Selain itu, perhitungan persentase setiap indikator pemahaman matematis siswa dihitung menggunakan rumus (Sudijono, 2010).

$$
P=\frac{f}{N} \times 100 \%
$$

Keterangan:

$\mathrm{f} \quad=$ frekuensi yang sedang dicari presentasenya

$\mathrm{N}=$ Number of Cases (Jumlah frekuensi/ banyaknya individu)

$\mathrm{P} \quad=$ angka persentase

Selanjutnya persentase pemahaman matematis per indikator tersebut dapat dikualifikasikan berdasarkan Adaptasi dari Arikunto (Zulkarnain \& Djamilah, 2015) sebagai berikut.

Tabel 2. Kualifikasi Persentase Pemahaman Matematis Per Indikator

\begin{tabular}{lc}
\hline \multicolumn{1}{c}{ Presentase $(\%)$} & Kualifikasi \\
\hline $81-100$ & Sangat Tinggi \\
$60-80,99$ & Tinggi \\
$41-60,99$ & Cukup \\
$21-40,99$ & Rendah \\
$0-20,99$ & Sangat Rendah \\
\hline
\end{tabular}

Selain menggunakan deskriptif kuantitatif, penelitian ini juga menggunakan statistik deskriptif. Statistik deskriptif yang digunakan dalam penelitian ini adalah mean (rata-rata). Rata-rata tersebut digunakan untuk memutuskan apakah penelitian tersebut perlu dilanjutkan pada siklus selanjutnya. Perhitungannya menggunakan rumus dari Sudijono (2010).

$$
\mathrm{M}_{\mathrm{x}}=\frac{\sum \mathrm{x}}{\mathrm{N}}
$$

Keterangan:

$\mathrm{M}_{\mathrm{x}}=$ Mean yang kita cari

$\Sigma \mathrm{x}=$ Jumlah dari skor- skor (nilai- nilai) yang ada

$\mathrm{N}=$ Number of Cases (banyaknya skor- skor itu sendiri)

Selanjutnya nilai rata-rata pemahaman matematis tersebut diinterpretasikan menurut tabel 3 adaptasi Ningsih (dalam Mawaddah \& Maryanti, 2016) berikut ini.

Tabel 3. Interpretasi Nilai Rata- Rata Pemahaman Matematis

\begin{tabular}{lc}
\hline \multicolumn{1}{c}{ Nilai } & Kriteria \\
\hline $85,00-100$ & Sangat Baik \\
$70,00-84,99$ & Baik \\
$55,00-69,00$ & Cukup \\
$40,00-54,99$ & Rendah \\
$0,00-39,00$ & Sangat Rendah \\
\hline
\end{tabular}




\section{HASIL DAN PEMBAHASAN}

Kondisi awal pada penelitian ini menunjukkan bahwa pemahaman matematis siswa kelas X IPA 1 SMA Muhammadiyah 4 Surabaya masih rendah dengan rata- rata 48,62. Dari 29 Siswa kelas X IPA 1 SMA Muhammadiyah 4 Surabaya, siswa yang dapat menyatakan ulang konsep yang telah dipelajari sebanyak 17 siswa $(58,62 \%)$, siswa yang dapat menerapkan konsep secara algoritma sebanyak 12 siswa (41,38\%), siswa yang dapat memberikan contoh dan counter example dari konsep yang telah dipelajari sebanyak 6 siswa (20,69\%), siswa yang dapat menyajikan konsep dalam berbagai macam representasi matematika sebanyak 3 siswa $(10,34 \%)$, serta tidak ada siswa yang dapat mengaitkan berbagai konsep $(0 \%)$.

Rendahnya pemahaman matematis siswa dikarenakan berbagai faktor antara lain penyampaian materi yang menggunakan metode ceramah dianggap siswa kurang menyenangkan dan monoton. Siswa juga merasa jenuh karena siswa kurang dilibatkan dalam pembelajaran. Selain itu, siswa beranggapan bahwa matematika adalah pelajaran yang sulit.

Retnowati (2013) mengatakan bahwa faktor lain yang menentukan keberhasilan pembelajaran matematika adalah disposisi matematis siswa. Banyak siswa yang beranggapan bahwa matematika merupakan mata pelajaran yang sulit dan kurang diminati. Anggapan tersebut muncul karena siswa kesulitan dan kurang gigih mengerjakan soal matematika, kurangnya keingintahuan serta kepercayaan diri siswa dalam belajar matematika. Sikap-sikap siswa yang dapat menumbuhkan disposisi matematis adalah antusias belajar matematika, gigih mengerjakan soal matematika, percaya diri, dan rasa ingin tahu. Selain itu, Jannah, dkk. (2016) mengatakan bahwa mata pelajaran matematika kurang disukai olah siswa, disebabkan guru masih membelajarkan matematika dengan menggunakan komunikasi satu arah, umumnya dari guru ke siswa, dengan begitu pembelajaran yang terjadi cenderung monoton sehingga mengakibatkan peserta didik cepat bosan, jenuh, dan akan mengakibatkan siswa kurang serius untuk mempelajarinya.

Hasil dari pelaksanaan siklus I menunjukkan bahwa siswa yang dapat menyatakan ulang konsep yang telah dipelajari sebanyak 21 siswa $(72,41 \%)$, siswa yang dapat menerapkan konsep secara algoritma sebanyak 25 siswa (86,21\%), siswa yang dapat memberikan contoh dan counter example dari konsep yang telah dipelajari sebanyak 17 siswa $(58,62 \%)$, siswa yang dapat menyajikan konsep dalam berbagai macam bentuk representasi matematika sebanyak 23 siswa $(79,31 \%)$, siswa yang dapat mengaitkan berbagai konsep (internal dan 
eksternal) sebanyak 7 siswa $(24,14 \%)$. Pada siklus I ini, tingkat pemahaman matematis siswa kelas X IPA 1 SMA Muhammadiyah 4 Surabaya telah mengalami peningkatan yang optimal yaitu dengan rata- rata 80,34. Kriteria pemahaman matematis mereka meningkat dari kategori rendah menjadi baik. Oleh karena itu, penelitian telah berhasil dan tidak memerlukan siklus selanjutnya.

Keberhasilan pada tahap siklus I terjadi karena beberapa faktor. Diantaranya yaitu adanya perpaduan antara model pembelajaran treffinger dan media pembelajaran IT berbasis software sparkol videoscribe sehingga siswa tidak merasa jenuh saat pembelajaran berlangsung. Selain itu, siswa juga menjadi aktif dalam pembelajaran. Siswa tertarik dengan software sparkol videoscribe karena mereka baru pertama kali merasakan pembelajaran di kelas menggunakan software tersebut. Siswa juga sangat antusias saat diajukan soal yang melibatkan proses berpikir divergen mereka. Mereka menjadi lebih bisa berekspresi dengan berbagai jawaban mereka tanpa memandang kesalahan.

Hal itu sesuai dengan manfaat yang bisa diperoleh dari menerapkan model treffinger menurut Shoimin (2014) diantaranya: (1) memberi kesempatan kepada siswa untuk memahami konsep- konsep dengan cara menyelesaikan suatu permasalahan; (2) membuat siswa aktif dalam pembelajaran; (3) mengembangkan kemampuan berpikir siswa karena disajikan masalah pada awal pembelajaran dan memberi keleluasaan kepada siswa untuk mencari arah-arah penyelesaian sendiri; (4) mengembangkan kemampuan siswa untuk mendefinisikan masalah, mengumpulkan data, menganalisis data, membangun hipotesis, dan percobaan untuk memecahkan suatu permasalahan; dan (5) membuat siswa dapat menerapkan pengetahuan yang sudah dimilikinya kedalam situasi baru.

Retnowati (2013) dalam penelitiannya menyimpulkan bahwa penerapan model model treffinger dapat meningkatkan pemahaman konsep dan disposisi matematis siswa kelas X 2 SMA Muhammadiyah 2 Surakarta. Hal ini dapat dibuktikan dengan peningkatan tiap indikator. Penelitian yang dilakukan oleh Indah Sari menunjukkan terjadi peningkatan hasil belajar siswa, siklus I sebanyak 14 orang dengan presentase 37,83\%, sedangkan pada siklus II sebanyak 32 orang dengan persentase $86,48 \%$ dan terjadi peningkatan aktivitas belajar siswa, Semangat siswa dalam mengikuti pembelajaran IPA Terpadu pada siklus I 50,15\% dan meningkat pada siklus II menjadi 80,05\%. Hasil penelitian ini menunjukkan bahwa penerapan model pembelajaran Treffinger dengan bantuan media audio visual dapat meningkatkan hasil 
belajar IPA Terpadu pada materi ekosistem pada siswa kelas VII A SMP FRATER Makassar. Model pembelajaran Treffinger juga dapat meningkatkan aktivitas dan hasil belajar siswa pada mata pelajaran IPA.

Penggunaan model pembelajaran treffinger dalam pembelajaran matematika dapat meningkatkan kemampuan representasi matematis siswa. hasil tersebut diperoleh dari penelitian yang dilakukan oleh Nurhasanah (2016) Pada aspek visual dari siklus I sebesar 70\% menjadi 79\% pada siklus II. Pada aspek ekspresi matematis dari siklus I sebesar 60\% menjadi $73 \%$ pada siklus II. Pada aspek teks tertulis dari siklus I sebesar $65 \%$ menjadi $76 \%$ pada siklus II. Adapula aspek kemampuan representasi matematis yang mengalami peningkatan cukup tinggi yaitu pada aspek visual dengan peningkatan sebesar $13 \%$.

Berdasarkan penjelasan sebelumnya, dapat disimpulkan bahwa penelitian yang dilakukan peneliti dapat memperkuat penelitian-penelitian terdahulu yang sudah dilakukan oleh Retnowati (2013) dan Oktavia (2017). Hasil penelitian yang dilakukan oleh Oktavia (2017) menunjukkan bahwa model pembelajaran treffinger dapat mendorong siswa untuk belajar secara kreatif. Selain itu penelitian yang dilakukan oleh Nurhasanah (2016) menunjukkan bahwa penggunaan model pembelajaran treffinger dalam pembelajaran matematika dapat meningkatkan kemampuan representasi matematis siswa. Data-data penelitian menunjukkan bahwa penelitian ini telah mencapai kenaikan rata- rata yang optimal. Hal itu membuktikan bahwa penggunaan model treffinger dapat meningkatkan pemahaman matematis siswa kelas X IPA 1 SMA Muhammadiyah 4 Surabaya.

\section{KESIMPULAN}

Pemahaman matematis siswa melalui penerapan model pembelajaran treffinger berbantukan software sparkol videoscribe adalah baik dengan rata- rata 80,34. Berdasarkan penelitian ini diharapkan para guru matematika untuk dapat menggunakan media pembelajaran dengan software sparkol videoscribe dan model pembelajaran treffinger. Model pembelajaran treffinger berbantukan software sparkol videoscribe mampu meningkatkan pemahaman matematis siswa. Diharapkan untuk peneliti lanjutan dapat mengembangkan media pembelajaran dengan software sparkol videoscribe dan model pembelajaran treffinger pada materi lainnya dan memperhatikan penggunaan waktu agar lebih efektif dan efisien. 


\section{REKOMENDASI}

Dalam kesimpulan dapat juga ditambahkan prospek pengembangan dari hasil penelitian dan aplikasi lebih jauh yang menjadi prospek kajian berikutnya.

\section{UCAPAN TERIMAKASIH}

Ucapan terima kasih ditujukan kepada SMA Muhammadiyah 4 Surabaya yang telah memberika kesempatan untuk melakukan penelitian ini.

\section{REFERENSI}

Dahlan, J. A. (2014). Analisis Kurikulum Matematika. Penerbit Universitas Terbuka, Jakarta.

Huda, M. (2013). Model- Model Pengajaran dan Pembelajaran. Yogyakarta: Pustaka Pelajar.

Jannah, R. dkk. (2016). Peningkatan Hasil Belajar Siswa pada Materi Mengubah Pecahan Biasa ke Bentuk Desimal dan Persen dengan Metode Discovery di Kelas V SD Negeri 1 Peusangan. Jupendas, 3, 1.

Mawaddah, S dan Maryanti, R. (2016). Kemampuan Pemahaman Konsep Matematis Siswa SMP dalam Pembelajaran Menggunakan Model Penemuan Terbimbing (Discovery Learning). EDU-MAT Jurnal Pendidikan Matematika, 4(1), 76-85.

Nurhasanah. (2016). Penerapan Model Pembelajaran Treffinger Untuk Meningkatkan Kemampuan Representasi Matematis Siswa. Skripsi tidak diterbitkan. Jakarta: Universitas Islam Negeri Syarif Hidayatullah.

Nurkaeti, N. (2017). Analisis Kemampuan Pemahaman dan Berpikir Kreatif Matematis Melalui Soal Pemecahan Masalah di Sekolah Dasar. Prosiding Seminar Nasional Membangun Generasi Emas 2045 yang Berkarakter dan Melek IT dan Pelatihan Berpikir Suprarasional, 314-315. Sumedang: Universitas Pendidikan Indonesia.

Oktavia, I. A. (2017). Penerapan Model Pembelajaran Treffinger pada Materi Bangun Ruang Sisi Datar. MATHEdunesa, 6(1). 
Retnowati, D. (2013). Upaya Meningkatkan Pemahaman Konsep dan Disposisi Matematis Menggunakan Model Pembelajaran Treffinger. Skripsi diterbitkan. Surakarta: Universitas Muhammadiyah Malang.

Safar, A. H. (2016). Educating Nonlinearly and Visually in the Digital Knowledge Age: A Delphi Study. Asian Social Science, 12(4).

Sanjaya, W. (2011). Penelitian Tindakan Kelas. Jakarta: Kencana Prenada Media Group.

Shoimin, A. (2014). 68 Model Pembelajaran Inovatif dalam Kurikulum 2013. Yogyakarta: ArRuzz Media.

Sudijono, A. (2010). Pengantar Statistik Pendidikan. Jakarta: Rajawali Pers.

Sudijono, A. (2011). Pengantar Evaluasi Pendidikan. Jakarta: Rajawali Pers.

Susanti, E. \& Syam, S. S. (2017). Peran Guru dalam Meningkatkan Kemampuan Literasi Matematika Siswa Indonesia. Prosiding Seminar Nasional Matematika dan Pendidikan Matematika yang diselenggarakan oleh FMIPA UNY 2017.

Zulkarnain, I. \& Djamilah, S. (2015). Penerapan Model Think Pair Share terhadap Kemampuan Pemahaman Matematis Siswa Sekolah Menengah Pertama. EDU-MAT Jurnal Pendidikan Matematika, 3(1), 105-117. 
